\title{
ВМј Global Health No right to food and nutrition in the SDGs: mistake or success?
}

To cite: Vivero Pol JL Schuftan C. No right to food and nutrition in the SDGs: mistake or success? BMJ Global Health 2016;1: e000040. doi:10.1136/ bmjgh-2016-000040

JLVP and CS highlight the implications and consequences of this absence as a fait accompli and explain the domestic and foreign positions of influential actors.

Received 10 February 2016 Revised 6 April 2016 Accepted 7 April 2016

\section{CrossMark}

${ }^{1}$ BIOGOV Unit, Centre for Philosophy of Law and Earth and Life Institute, Université Catholique de Louvain, Louvain-la-Neuve, Belgium ${ }^{2}$ People's Health Movement, Ho Chi Minh City, Vietnam

\section{Correspondence to} Jose Luis Vivero Pol; jose-luis.viveropol@ uclouvain.be

\begin{abstract}
Although the recently approved Sustainable Development Goals (SDGs) explicitly mention access to water, health and education as universally guaranteed human rights, access to affordable and sufficient food is not given such recognition. The SDGs road map assumes that market mechanisms will suffice to secure nutritious and safe food for all. We question how and why the right to food has disappeared from such an international agreement and we will provide insights on the likely causes of this and the options to make good on such a regrettable omission. Analysis of political stances of relevant western stakeholders, such as the United States (US) and the European Union (EU), is also included.
\end{abstract}

If we are to follow the guidance provided by the Sustainable Development Goals (SDGs) recently approved, ${ }^{1}$ the fight against malnutrition and the achievement of the United Nations (UN)'s 'Zero Hunger Challenge" ${ }^{\text {, }}$ will not be guided by the human right to adequate food (and nutrition). ${ }^{3}$ Although the SDGs explicit access to water, health and education as universally guaranteed human rights, access to affordable and sufficient food is not given such recognition. The SDGs road map assumes that market mechanisms will suffice to secure nutritious and safe food for all. We question how and why the right to food has disappeared from such an international agreement and we will provide insights on the likely causes of this and the options to make good on such a regrettable omission.

\section{NO COMPASS FOUND IN THE SDGS TO ELIMINATE HUNGER}

The latest UN General Assembly (September 2015) approved this non-binding road map to guide the world's development towards prosperity and well-being for the next 15 years. The SDGs were drafted in extenuating diplomatic negotiations. In order to reach a consensus document, concepts that were deemed unacceptable to some member states were either disposed of, polished with softening adjectives, reworded or simply

\section{Key questions}

What is already known about this topic?

- The right to food, so closely linked to the fundamental right to life, is a formal human right, increasingly recognised in many countries, jurisprudence in the field is growing, and the links developed with other constituencies (food sovereignty and nutrition) reinforce its mandate and political priority.

\section{What are the new findings?}

- And yet, contrary to the international consensus reached during the past 50 years, food is not regarded as a human right in the Sustainable Development Goals (SDGs) document. This article denounces this omission which indeed has important political and legal implications.

- The full realisation of this human right is not favoured by the openly adamant US opposition as well as the dual EU attitude: promoting its applicability for the others in international negotiations and being lax at domestic level with no reference in legal frameworks.

\section{Recommendations for policy}

- In human rights-friendly countries, develop national legal frameworks that include the right to food; further conceptualise and implement Universal Food Coverage schemes similar to those guaranteeing universal access to health and education; human rights-friendly countries and public interest civil society organisations to keep a vigilant attitude so as to defend the agreed minimum standards of the right to food in international negotiations; and de-construct the dominant narrative of food as a commodity so as to replace it by a human rights narrative placing food squarely as a human right, a commons and a public good.

avoided during the final negotiations in July 2015-even those that had previously attained a broad consensus in binding international agreements. The right to food serves as a striking example.

The ample consensus reached in the second half of the 20th century over universal access to healthcare ${ }^{4}$ and education ${ }^{5}$ as a means to address wealth inequalities did not cover the universal access to food. The 190 
plus countries that approved the SDGs document had a unique chance to do the same for the right to food, but chose, or were resigned, not to do so. As a consequence, food is not given the status of a human right ${ }^{6}$ in the document, implying that the existing market mechanisms are good enough to address the food needs of every human being (see box 1). This is clearly a legal and diplomatic regression from previous international agreements such as the Universal Declaration of Human Rights ${ }^{7}$ and the International Covenant on Economic, Social and Cultural Rights ${ }^{8}$ with its very specific General Comment. ${ }^{9}$ This is evidently intentional as the SDGs do reaffirm the human right to safe drinking water and sanitation.

Why has universal access to food, the right that has to be met before being able to enjoy other civil, political, social and economic rights, ${ }^{10}$ not been awarded the same level of importance as education, health or water? The explanations, collected informally by the authors, are that several influential countries and institutions were adamantly opposed to the consideration of food as a human right. Yet many of those opponents did sign and ratify the International Covenant on Economic, Social and Cultural Rights, the binding agreement that indeed includes this right in its provisions. Moreover, a growing number of countries are explicitly protecting the right to food by either including it in their constitutions, ${ }^{11}$ enacting food security laws ${ }^{12}$ or pursuing rights-based food and nutrition security strategies and policies. ${ }^{13}$ This proves the lack of coherence that often comes to the fore during international negotiations: human rights commitments are pitched against economic interests.

\section{THE OPPONENTS TO THE RIGHT TO FOOD}

Although it is difficult to find official government statements that categorically deny or oppose the rights-based approach to food (the US government's position being an exception), several countries, regional organisations and international institutions have consistently and openly not been sympathetic to the right to food provisions. Countries like Canada, ${ }^{14}$ the $\mathrm{US}^{15}{ }^{16}$ and several

\section{Box 1 The first paragraph of the Sustainable} Development Goals vision states the following:

(Para 7) In these Goals and targets, we are setting out a supremely ambitious and transformational vision. We envisage a world free of poverty, hunger, disease and want, where all life can thrive. We envisage a world free of fear and violence. A world with universal literacy. A world with equitable and universal access to quality education at all levels, to healthcare and social protection, where physical, mental and social well-being are assured. A world where we reaffirm our commitments regarding the human right to safe drinking water and sanitation and where there is improved hygiene; and where food is sufficient, safe, affordable and nutritious. A world where human habitats are safe, resilient and sustainable and where there is universal access to affordable, reliable and sustainable energy. (emphasis added)
EU members have never considered incorporating the right to food into their Constitutions or national legal frameworks. This position vis-a-vis the right to food is encouraged and complemented by the lack of support for this right (except for mere lip service) by international organisations such as the G-8, G-20, the World Economic Forum, the World Trade Organisation, the World Bank and the International Monetary Fund. ${ }^{17} 18$ Moreover, most transnational corporations and philanthropic foundations do not feel bound by binding human rights principles either. ${ }^{19}$ So, although the US may behave as an outlier in the emerging global consensus on economic and social rights, its hegemonic power in international institutions and fora results in a regular and predictable blocking of any attempt to insert social rights-based provisions in global discussions. Additionally, other countries, although not publicly voicing their opposition, quietly obstruct the realisation of the right to food in areas of their own jurisdiction. ${ }^{20}$ With so many foes, it is understandable, but not acceptable, that no mention of the right to food is found in the SDGs document.

\section{THE RECURRENT US POSITION: 'FOOD IS NOT A RIGHT'}

The US has steadily opposed any internationally agreed document that considers food as a human right. It is the only nation that has neither ratified the Convention on the Rights of the Child nor the International Covenant on Economic, Social and Cultural Rights. Moreover, it was the only nation that refused to sign the final declaration of the 1996 World Food Summit and it stood alone in opposing the right to food being included in the 2002 World Food Summit declaration. ${ }^{21}$ Actually, the US included an official reservation to the paragraph referring to the right to food ${ }^{22}$ (see box 2), arguing that the

Box 2 What was the US Official Reservation to the 2002 World Food Security Declaration regarding the Right to Food?

The US believes that the issue of adequate food can only be viewed in the context of the right to a standard of living adequate for health and well-being, as set forth in the Universal Declaration of Human Rights, which includes the opportunity to secure food, clothing, housing, medical care and necessary social services. Further, the US believes the attainment of the right to an adequate standard of living is a goal or aspiration to be realised progressively that does not give rise to any international obligation or any domestic legal entitlement, and does not diminish the responsibilities of national governments towards their citizens. Additionally, the US understands the right of access to food to mean the opportunity to secure food, and not guaranteed entitlement. Concerning Operative Paragraph 10, we are committed to concrete action to meet the objectives of the World Food Summit, and are concerned that sterile debate over 'Voluntary Guidelines' would distract attention from the real work of reducing poverty and hunger. (emphasis added) 
right to food cannot give rise to any binding state duty or guaranteed citizen entitlement, both at domestic and international levels, to feed the hungry adequately. For the US government, food is just a commodity whose access is exclusively guaranteed by purchasing power or charitable schemes. Moreover, this stance vis a vis the right to food has to be understood as just one component of the government's long-standing broad resistance to economic, social and cultural rights in general.

The US has even refused to accept non-binding resolutions on the subject, although during President Obama's mandate this recurrent stance has been softened and the US joined a non-binding UN Declaration on the Right to Food in $2009^{23}$ while issuing supplemental explanations. Yet in 2014, it blocked a draft resolution on the same right. ${ }^{24}$ Official explanatory notes reaffirmed its traditional areas of disagreement, namely this right just being a 'desirable policy goal' not carrying any enforceable obligation. ${ }^{25}$ This opposition, which has rendered this right non-justiciable in the Inter-American Court of Human Rights, ${ }^{26}$ does not prevent the generously funded and needs-based food security programmes at home and abroad (ie, the Supplemental Nutrition Assistance Programme or Feed the Future), programmes that are voluntary, not universal, accountable or justiciable and determined by political priority fluctuations and budgetary constraints. ${ }^{27}$

\section{THE EUROPEANS' DOUBLE STANDARDS: SUPPORTING ABROAD, RELUCTANT AT HOME}

The EU authorities have repeatedly said that states should 'mainstream a human rights perspective in their national strategies for the realisation of the right to adequate food for all' ${ }^{28}$ After the Treaty of Lisbon, ${ }^{29}$ a binding agreement of high legal and political relevance, all member states and the European Commission have the legal obligation to respect, protect and promote human rights within its territory and in EU-supported interventions in other countries. Of course, that should include all the internationally recognised human rights, such as the right to food. Moreover, the Commission has expressed its support to 'right to food-based political and legal frameworks' in developing countries, as well as establishing and strengthening redressal mechanisms. ${ }^{30}$ Likewise, the European Parliament has taken a similar position regarding the relevance of the right to food to address food security challenges in developing countries. ${ }^{31}$

Yet no EU member state recognises explicitly the right to food in their Constitutions ${ }^{32}$ or in specific laws; nor is any mention to the right to food made in the fundamental European Treaties: No right to food in the European Social Charter, ${ }^{33}$ adopted in 1961 and revised in 1996 that actually extends the protection of social and economic rights to the Council of Europe members; or in the EU Charter of Fundamental Rights, ${ }^{34}$ adopted in 2000 as legally binding; it is supposed to include rights from international instruments ratified by all European members (ie, International Covenant on Economic, Social and Cultural Rights); or in the European Convention on Human Rights, ${ }^{35}$ originally signed in 1950 and having been enriched with seven protocols. It is worth noting that the right to private property was included in the first article of the first protocol in 1952. Ergo, private property is a right for Europeans, but food is not.

\section{UNDERSTANDING THIS OPPOSITION}

It is not uncommon to see countries that, at the domestic or international level, consistently water down strong references to the right to food. Examples include insisting on rather fuzzy definitions of specific violations, opposing the awarding of monetary and non-monetary remedies, or softening the language in international agreements, often carried out in last-minute diplomatic negotiations. As shown in this article, the US deliberately characterises the right to food as an 'opportunity' rather than as an entitlement which removes any obligation for their government. Meanwhile, the Europeans have a dual attitude in this regard: whereas in the international arena they publicly defend and even finance this right to be implemented in other countries (ie, the Global South), at the domestic level they are barely doing anything to render this right operational within the EU boundaries despite food insecurity being on the rise; ${ }^{36}$ food is not yet a European right.

Several reasons may explain the US opposition and the EU's attitude. Some argue that this right is not included in the US Constitution and therefore does not resonate with the American culture. ${ }^{37}$ Others state that its definition confuses human rights priorities. ${ }^{38}$ Another explanation is that both adhere to an ideological stance in which market-based resources distribution is far more efficient than a rights-based scheme for such a vital resource. The privatisation of food-producing inputs (soil, seeds, water) and the absolute commodification of the final output (food) confirm the dominant discourse of both actors and hence in the international institutions they control (ie, World Trade Organization, International Monetary Fund, World Bank, World Economic Forum). ${ }^{39}$ Those institutions are adamant about the absolute validity of market mechanisms to distribute food as a commodity. Therefore, the duties and entitlements guaranteed by the right to food clearly collide with this position.

\section{CAN THIS POSITION BE REVERSED? EXPLORING THE OPTIONS}

The absence of this right from the SDGs can be interpreted as both a success for US diplomacy and a crass mistake for the Global South and EU countries in their final bargaining to arrive at a consensus document. We are obviously faced with a fait accompli 
here, and it is pointless to propose a revision of the SDGs document. ${ }^{40}$ Nevertheless, inaction is not an option either and the focus shall be in rendering effectively this right at the national level by developing legal frameworks. Therefore, food as a human right must attain the same status as education and health in European regional and national legislations-a commendable first step. Belgium is already drafting such a law and the Lombardia Region has issued an ad hoc law recently. These examples can pave the way for the deployment of Universal Food Coverage schemes in the increasingly food-insecure Europe. Then, once enshrined at home, the EU could advocate for the incorporation of rights-based provisions in international agreements dealing with food (ie, in the World Trade Organization, bilateral trade agreements, Codex Alimentarius). The US case proves to be harder and only reversible through a combined mix of local struggles and domestic rights-based campaigns (ie, on food justice, community supported agriculture, agricultural labourer's rights) on the one side and international leverage by international institutions, peer countries and media campaigns on the other.

The right to food has already progressed substantially in a few countries, with 10 right to food laws, 15 Parliamentary Fronts Against Hunger in Latin America and a growing jurisprudence using the right to food in more than 50 cases in 28 countries (just two in the EU and none in the US, however). ${ }^{41}$ The right to food constituency is gaining momentum thanks to its alliance with the food sovereignty movement and the closer links being developed with the nutritional constituency, ${ }^{42} 43$ as well as confronting the mounting corporatisation of nutrition and the food system. ${ }^{44}$ Part of this constituency has set up the Global Network for the Right to Food and Nutrition ${ }^{45}$ and network members did exert pressure during the preparatory phase of the SDGs, alas to no avail. However, they are organised to take things further, locally and globally, in the years to come. Finally, although solely coming up with legal frameworks to protect this right will not suffice-since several countries have good laws that are only weakly implemented-rendering effectively this right at the national level will indeed be a useful rallying point in the struggle for a food-secure world. Since food is a right and not a commodity and eating remains a vital need, food and nutrition security must be considered a right of all people rather than a development goal carrying no accountability.

\section{Handling editor Seye Abimbola}

Twitter Follow Jose Luis Vivero Pol at @joseLviveropol

Contributors JLVP is researching the motivations and institutional settings that govern food system transitions in developed and developing countries. CS is an international public health nutrition activist and member of the Steering Council of the People's Health Movement. For many years, both authors have been directly involved in national and international negotiations to promote the right to food. JLVP undertook the legal screening for this paper. Both contributed to the writing of the manuscript and policy analysis. JLVP is the guarantor.

Funding European Research Council. GENCOMMONS (ERC agreement 284). European Commission, BIOMOT (FP-7 agreement 282625). Belgian Science Policy Office, Food4Sustainability, BRAIN-be BR/121/A5. OpenAire FP-7 Postgrant open access pilot.

Competing interests JLVP has received funding from the Belgian Science Policy Office, under the project Food4Sustainability, and the European Commission, under the FP7 project BIOMOT and ERC Project GENCOMMONS. CS declares no conflicts of interest.

Provenance and peer review Not commissioned; externally peer reviewed.

Data sharing statement No additional data are available.

Open Access This is an Open Access article distributed in accordance with the Creative Commons Attribution Non Commercial (CC BY-NC 4.0) license, which permits others to distribute, remix, adapt, build upon this work noncommercially, and license their derivative works on different terms, provided the original work is properly cited and the use is non-commercial. See: http:// creativecommons.org/licenses/by-nc/4.0/

\section{REFERENCES}

1. United Nations. Transforming our world: the 2030 agenda for sustainable development. Resolution adopted by the Genera Assembly on 25 September 2015. UN Doc A/RES/70/1. http://www. un.org/ga/search/view_doc.asp?symbol=A/RES/70/1\&Lang=E

2. Initiative launched by UN Secretary-General Ban Ki-moon in 2012 as his personal vision, and a sort of legacy. It is a global call to action to achieve zero hunger within our generation based on five targets: zero stunting in children under 2 years, everybody having access to sustainable food all year around, all food producing systems being running sustainably, doubling smallholder productivity and income and zero food waste. http://www.un.org/en/zerohunger/ challenge.shtml

3. In this text, we will be using the term 'right to food' as an abridged version of the cluster encompassing the human right to adequate food and the fundamental right to be free from hunger. Additionally, the term also includes recent proposals to broaden its scope to nutritional domains.

4. Kruk ME. Universal health coverage: a policy whose time has come. BMJ 2013;347:f6360.

5. Muedini F. Human rights and universal child primary education. New York: Palgrave Macmillan, 2015.

6. The rights-based approach to food and nutrition security differs from the needs-based approach in that the former demands government accountability, active engagement of food insecure people in policy governance, universal access policies, legal redress mechanisms and more binding connections between policies and outcomes; whereas the latter assumes people who lack access to food are passive recipients in need of direct assistance, without governmenta obligations or justiciability. See also: Chilton M, Rose D. A rights-based approach to food insecurity in the United States. Am J Public Health 2009:99:1203-11.

7. United Nations. Universal Declaration of Human Rights art. 25(1). General Assembly resolution 217A. 12 December 1948. UN Doc A/ 810. http://www.un.org/en/documents/udhr

8. United Nations. International Covenant on Economic, Social and Cultural Rights art. 11. General Assembly resolution 2200 (XXI). 16 December 1966. UN Doc. A/6316. http://www2.ohchr.org/english/ law/pdf/cescr.pdf

9. United Nations. Committee on Economic, Social and Cultural Rights General Comment 12: the right to adequate food. 12 May 1999. UN Doc. E/C.12/1999/5. http://www.unhchr.ch/tbs/doc.nsf/(Symbol)/ 3d02758c707031d58025677f003b73b9?Opendocument

10. Shue H. Basic rights: subsistence, affluence, and U.S. foreign policy. Princeton: Princeton University Press, 1996.

11. Vidar M, Kim YJ, Cruz L. Legal developments in the progressive realization of the right to adequate food. Thematic study. Rome: Food and Agriculture Organisation of United Nations Legal Office, 2014. http://www.fao.org/3/a-i3892e.pdf

12. Vivero Pol JL. El enfoque legal contra el hambre: el derecho a la alimentación y las leyes de seguridad alimentaria. In: Erazo X, Pautassi L, Santos A, eds. Exigibilidad y realización de derechos sociales. Impacto en la política pública. Santiago: Editorial LOM, Santiago, 2010:163-88. Spanish. 
13. De Schutter $O$. The transformative potential of the right to food. Report submitted to the United Nations Human Rights Council, 24 January 2014, UN Doc. A/HRC/25/57. http://www.srfood.org/images/ stories/pdf/officialreports/20140310 finalreport en.pdf

14. Margulis ME. Forum-shopping for global food security governance? Canada's approach at the G8 and UN committee on world food security. Can Foreign Policy J 2015;21:164-78.

15. Lewis H. "New" human rights? U.S. ambivalence toward the international economic and social rights framework. In: Soohoo C, Albisa C, Davis MF, eds. Bringing human rights home: a history of human rights in the United States. Philadelphia: University of Pennsylvania Press, 2009:100-41.

16. Messer E, Cohen MJ. The human right to food as a U.S. nutrition concern, 1976-2006. IFPRI Discussion Paper 731. Washington: International Food Policy Research Institute, 2007. http://www.ifpri. org/publication/human-right-food-us-nutrition-concern-1976-2006

17. Lambek N. The right to food: reflecting on the past and future possibilities. Synthesis paper. Can Food Stud 2015;2:68-74.

18. Ziegler J, Golay C, Mahon C, et al. The fight for the right to food: lessons learned. London and New York: Palgrave MacMillan, 2011.

19. Narula S. Reclaiming the right to food as a normative response to the global food crisis. Yale Hum Rights Dev Law J 2011;13:403-20.

20. Ospes O, van der Meulen B. Fed up with the right to food? The Netherlands' policies and practices regarding the human right to adequate food. Wageningen: Wageningen Academic Publishers, 2009:102.

21. Rosset P. US Opposes right to food at World Summit. Oakland: Food First and Institute for Food and Development Policy, 2002. http://www.mindfully.org/Food/Right-To-Food30jun02.htm

22. Reservation made on operative paragraph 10 by Carolee Heileman, Acting Permanent Representative of US mission to the UN agencies for food and agriculture, Rome. http://www.fao.org/docrep/meeting/ 005/y7106e/y7106e03.htm\#P192_62571

23. United Nations. The right to food. UN General Assembly resolution UN Doc. A/RES/63/187. 17 March 2009. http://www.un.org/en/ga/ search/view_doc.asp?symbol=A/RES/63/187

24. United Nations. The right to food. Draft resolution UN Doc. A/C.3/69/ L.42. http://daccess-dds-ny.un.org/doc/UNDOC/GEN/N14/600/94/ PDF/N1460094.pdf?OpenElement This draft proposal was not approved (as it can be seen in the official UN website http://www.un. org/en/ga/70/resolutions.shtml)

25. Explanation of position on Agenda Item 68(b), L.42: Right to Food. United States Mission to the United Nations. Terri Robl, U.S. Deputy Representative to the UN Economic and Social Council. 25 November 2014. http://usun.state.gov/remarks/6295

26. Vivero Pol JL. Hunger for justice in Latin America. The justiciability of the right to food. In: Martin MA, Vivero Pol JL, eds. New challenges to the right to food. Barcelona: Huygens Editorial, 2011:15-55.

27. Schuftan C. Targetry and equity. [Column] Website of the World Public Health Nutrition Association, August 2011. http://www.wphna. org/htdocs/2011_aug_col_claudio.htm

28. Explanation of position on behalf of the European Union by the Permanent Mission of Sweden to the United Nations, 64th Session of the General Assembly Third Committee, draft resolution L.30/ Rev.1 GA64: The Right to Food. European Union, 19 November 2009. http://eu- un.europa.eu/articles/en/article_9328_en.htm

29. Consolidated versions of the Treaty on European Union and the Treaty on the Functioning of the European Union. Official Journal of the
European Union, C 115 Volume 51. European Union, 9 May 2008. http://eur-lex.europa.eu/legal-content/EN/TXT/?uri=OJ:C:2008:115:TOC

30. Increasing the impact of EU Development Policy: an agenda for change. Communication from the Commission to the Council and the European Parliament. COM /2011/0637 Final. European Commission, 2011.

31. Assisting developing countries in addressing food security challenges. Resolution of 27 September 2011, (2010/2100). European Parliament, 2011.

32. Only Belarus, Ukraine and Moldova include a specific reference to this right in their Constitutions. In: Knuth L, Vidar M, eds. Constitutional and legal protection of the right to food around the world. Rome: Food and Agriculture Organisation of United Nations, 2011. http://www.fao.org/docrep/016/ap554e/ap554e.pdf

33. The European Social Charter. Council of Europe. 1996. https://rm coe.int/CoERMPublicCommonSearchServices/ DisplayDCTMContent?documentld $=090000168007 \mathrm{cde} 2$

34. Charter of fundamental rights of the European Union (2012/C 326/ 02). European Union, 2009. http://eur-lex.europa.eu/legal-content/ $\mathrm{EN} / \mathrm{TXT} / \mathrm{PDF} /$ ?uri=CELEX:12012P/TXT\&from=EN

35. European Convention on Human Rights. Council of Europe, 2010. http://www.echr.coe.int/Documents/Convention_ENG.pdf

36. Loopstra R, Reeves A, Stuckler D. Rising food insecurity in Europe. Lancet 2015;385:2041.

37. King S. Statement before the Republican Study Committee. Congressional Record 22 March 2007, H2946 [cited 2009 Feb 8]. In: Messer E, Cohen MJ, eds. US Approaches to Food and Nutrition Rights, 1976-2008. World Hunger Notes. http://www.worldhunger. org/articles/08/hrf/messer.htm

38. Alston P. U.S. ratification of the covenant on economic, social and cultural rights: the need for an entirely new strategy. Am J Int Law 1990;84:365-93.

39. Vivero Pol JL. What if food is considered a common good? The essential narrative for the food and nutrition transition. United Nations Standing Committee on Nutrition News 2013;40:85-9. http:// www.unscn.org/files/Publications/SCN_News/SCNNEWS40_31.03_ standard res nearfinal.pdf

40. Whether and how the inclusion of the right to food in the SDGs final document might have had real impact in the years to come remains an unanswered question, as many other global consensus statements have had little, if any, impact (i.e. Kyoto Protocol on climate change). This recognition by no means minimises the criticism levied in this article that denounces how political manoeuvres left a binding legal provision out of such an important international agreement.

41. International Development Law Organization. Realizing the right to food: legal strategies and approaches. 2015. http://www.idlo.int/sites/ default/files/pdfs/publications/Realizing\%20the\%20Right\%20to\% 20Food_Legal\%20Strategies\%20and\%20Approaches_full-report.pdf

42. De Schutter O. The right to adequate nutrition. Development 2014;57:147-54.

43. Valente FLS. Towards the full realization of the human right to adequate food and nutrition. Development 2014;57:155-70.

44. Bread for the World, FIAN International, ICCO Cooperation. Peoples Nutrition is Not a Business. Right to Food and Nutrition Watch 7. http://www.rtfn-watch.org

45. The Charter of this network can be found at: http://www.fian.org/ fileadmin/media/publications/GMRtFN - formatted charter.pdf 